ХУМАРОВА Н. I.

д-р екон. наук, професор,

2.н.с. відділу економічного регулювання природокористування

Інститут проблем ринку та економіко-екологічних досліджень НАНУ

Франиузький бульвар, 29, м. Одеса, Украйна, 65044

E-mail: khumarova@nas.gov.ua

ORCID: 0000-0001-5255-8004

\title{
ПЕТРУШЕНКО М. М.
}

д-р екон. наук,

завідувач відділу економічного регулювання природокористування

Інститут проблем ринку та економіко-екологічних досліджень НАНУ

Франиузький бульвар, 29, м. Одеса, Украӥна, 65044

E-mail: petrushenkom@gmail.com

ORCID: 0000-0003-0098-7872

ПРОКОПЮК А.

д-р екон. наук, професор, ректор

Вища економічна школа в Білосточі

вул. Перемоги, 14/3, м. Білосток, Республіка Польщза, 15-950

E-mail: aleksander.prokopiuk@wse.edu.pl

\section{IННОВАЦЙНЕ МОДЕЛЮВАННЯ АНТРОПОЕКОСИСТЕМИ В УМОВАХ INDUSTRY 4.0 НА ПРИКЛАДІ ПРИЧОРНОМОРСЬКОГО ЕКОНОМІЧНОГО РАЙОНУ ${ }^{1}$}

Актуальність. Всупереч уповільненню сочіально-економічного розвитку, загостренню збройних конфліктів, і впливу пандемії коронавірусу на всі сфери життя суспільства, об'єктивні умови промислового та науково-технічного розвитку Industry 4.0 сприяють прискоренню інноваційного розвитку в Україні.

Мета та завдання. Мета дослідження полягає в обгрунтуванні аспектів інновачійного моделювання розвитку антропоекосистеми, на прикладі комплексного аналізу соціальних та екологічних показників суб'єктивного оцінювання населення Украйни та перспектив рекреаційно-туристичного розвитку в Причорноморському економічному районі.

Результати. Обгрунтовано, щуо в антропоекосистемі центральним елементом с індивід, навколо якого функціонує природне та штучно створене середовище: в результаті еволюиіі антропоцентризму відносно настання фази Industry 4.0 домінуючим є Ното Economicus, щุo завдяки інклюзивному підходу та підтримиі держави утворює своєрідний симбіоз із Ното Socialis. Державне регулювання спрямоване на встановлення правил і стимулів інноваційної діяльності. Високий рівень розвиненості економіки потребує передусім дію механізму ринкового регулювання, щзо каталізуе інноваційний розвиток краӥни в тому числі в соиіальній та екологічній сферах. Поєднання та спільна дія механізмів державного, ринкового та сочіального регулювання $\epsilon$ обов'язковою передумовою формування політики реалізації Цілей сталого розвитку.

Висновки. В статті обтрунтовані та узагальнені аспекти інноваційного моделювання систем, що мають елементи економічного, соціального та екологічного розвитку в умовах Industry 4.0. Дослідження антропоекосистем є реагуванням на загострення стану навколишнього середовища, спричиненого поєднанням сочіально-економічної нестабільності та наслідків впливу пандемії коронавірусу на життя країни, регіону та індивіда. В роботі проведений порівняльно-рейтинговий аналіз показників суб'єктивного оцінювання населення економічний районів, зокрема, Причорноморського економічного району Украӥни. Розглянуті положення щзодо розвитку рекреації та туризму, інновачійність яких спрямована на подолання наслідків пандемї коронавірусу та економічну євроінтеграчію України.

Ключові слова: інклюзивний економічний розвиток, інноваційне моделювання, рекреація та туризм, сталість, Украӥнське Причорномор'я.

\footnotetext{
1 Дослідження виконане в рамках наукових тем: «Інклюзивність економіки вражень у природокористуванні (№ державної реєстрації 0119U000229) та «Домінанти інвестиційно-інноваційної політики природокористування національної економіки» (№ державної реєстрації 0120U100160).
} 
KHUMAROVA N. I.

Dr. Econ. Sciences, Chief Researcher,

Institute of Market Problems and Economic\&Ecological Research

of the National Academy of Sciences of Ukraine

Frantsuzskyi Boulevard, 29, Odesa, Ukraine, 65044

E-mail: khumarova@nas.gov.ua

ORCID: 0000-0001-5255-8004

PETRUSHENKO M. M.

Dr. Econ. Sciences, Head of Department,

Institute of Market Problems and Economic\&Ecological Research

of the National Academy of Sciences of Ukraine

Frantsuzskyi Boulevard, 29, Odesa, Ukraine, 65044

E-mail: petrushenkom@gmail.com

ORCID: 0000-0003-0098-7872

PROKOPIUK A.

Dr. Econ. Sciences, Professor, Rector

Bialystok School of Economics

Zwycięstwa 14/3, Biatystok, Republic of Poland, 15-950

E-mail: aleksander.prokopiuk@wse.edu.pl

\section{INNOVATIVE MODELING OF THE ANTROPOECOSYSTEM IN THE INDUSTRY 4.0 CONDITIONS ON THE EXAMPLE OF THE BLACK SEA ECONOMIC REGION}

Topicality. Despite the slowdown in socio-economic development, the escalation of armed conflicts, and the impact of the coronavirus pandemic on all spheres of society, the objective conditions of industrial and scientifictechnical development of Industry 4.0 contribute to the acceleration of innovative development in Ukraine.

Aim and tasks. The purpose of the study is to substantiate aspects of innovative modeling of anthropoecosystem development, on the example of a comprehensive analysis of indicators of subjective assessment of the population of Ukraine and prospects for recreational and tourist development in the Black Sea economic region.

Research results. It is substantiated that in the anthropoecosystem the central element is the individual around whom the environment operates: as a result of the evolution of anthropocentrism in relation to the Industry 4.0 phase, Homo Economicus dominates, which due to the inclusive approach and state support forms a symbiosis with Homo Socialis. State regulation is aimed at establishing rules and incentives for innovation. The high level of economic development requires first of all the operation of the market regulation mechanism, which catalyzes the innovative development of the country. The combination and joint action of mechanisms of state, market and social regulation is a prerequisite for the formation of policies for the implementation of the Sustainable Development Goals.

Conclusion. The article substantiates and generalizes aspects of innovative modeling of systems that have elements of economic, social and environmental development in Industry 4.0. Anthropoecosystem research is a response to the aggravation of the environment caused by a combination of socio-economic instability and the effects of the coronavirus pandemic on the lives of the country, region and individual. The paper presents a comparative rating analysis of indicators of subjective assessment of the population of economic regions, in particular, the Black Sea economic region of Ukraine. Provisions on the development of recreation and tourism, the innovation of which is aimed at overcoming the effects of the coronavirus pandemic and Ukraine's economic integration, are considered.

Keywords: inclusive economic development, innovative modeling, recreation and tourism, sustainability, Ukrainian Black Sea coast.

Постановка проблеми та їі зв'язок з важливими науковими та практичними завданнями. В умовах від’ємної синергії уповільнення соціально-економічного розвитку, номінальної реалізації концепції сталого розвитку, загострення збройних конфліктів, i наразі, головне, впливу пандемії коронавірусу на всі сфери життя суспільства (здоров'я людини постає центральним елементом у системах прийняття управлінських рішень; довкілля поряд із цим є також у полі підвищеної уваги) актуалізується комплексний міждисциплінарний теоретико-методологічний підхід, пов'язаний із дослідженням антропоекосистем [1]. Всупереч загальній нестабільній внутрішньоекономічній ситуації, об'єктивні умови промислового та науково-технічного розвитку Industry 4.0 сприяють прискоренню інноваційного розвитку в Україні. 
Причорноморський економічний район України в своєму інноваційному розвитку одним із основних напрямів має туризм і рекреацію, що можна розглядати як оновлення традицій і водночас підтримання нових світових тенденцій [2] розвитку людиноорієнтованої екологічно дружньої економічної діяльності.

Аналіз останніх публікацій по проблемі. Процеси інноваційного моделювання соціальних, економічних і технологічних систем описані в роботах [3-6]. Певним узагальнюючим відображенням концептуальних міждисциплінарних підходів до інноваційного моделювання розвитку соціальноекономічних систем є моделі Helix [7; 8]. Інноваційний імператив становлення «зеленої» економіки та, зокрема, аспекти державного управління природними активами; екологічні цільові програми у системі державного регулювання природокористування висвітлені в роботах Б. В. Буркинського, Н. І. Хумарової та ін. [9-11]. Чинники управління екологічною безпекою сталого розвитку враховані в результатах досліджень В. Ф. Грищенка, І. В. Грищенко та ін. [12-15]. Інноваційні, ринкові, регуляторні елементи системи розвитку туризму та рекреації як соціально-економічних процесів розкриті в роботах В. М. Кислого, Г. М. Шевченко та ін. [16-21].

Виділення невирішених раніше частин загальної проблеми. Поряд із цим подальшого дослідження потребує проблема інноваційного моделювання антропоекосистем, які функціонують в умовах Industry, передусім, на концептуальному рівні.

Формулювання цілей дослідження (постановка завдання). Мета дослідження полягає в обгрунтуванні аспектів інноваційного моделювання розвитку антропоекосистеми в об'єктивних індустріальних умовах, на прикладі комплексного аналізу показників суб'єктивного оцінювання населення України та перспектив рекреаційно-туристичного розвитку в Причорноморському економічному районі.

Виклад основних результатів та їх обгрунтування.

Еволюція антропоцентризму відносно зміни фаз Industry представлена на рис. 1: для фази Industry 4.0 домінуючою є Людина Економічна, що завдяки інклюзивному підходу та підтримці держави в демократичних суспільствах, утворює своєрідний симбіоз із Людиною Соціальною.

\begin{tabular}{|c|c|c|c|}
\hline \begin{tabular}{l}
\multicolumn{1}{c}{ Industry $\mathbf{0 . 5}$} \\
Розширення \\
споживання \\
природних ресурсів + \\
приручення тварин
\end{tabular} & $\begin{array}{l}\text { Industry1.0-2.0 } \\
\text { Сила води (пари): } \\
\text { від механізації - } \\
\text { до масового } \\
\text { виробництва }\end{array}$ & $\begin{array}{l}\text { Industry 3.0-4.0 } \\
\text { Дефіцит } \\
\text { ресурсів: } \\
\text { маловідходне } \\
\text { виробництво }\end{array}$ & $\begin{array}{c}\text { Industry5.0-6.0 } \\
\text { ШІ: передчуття } \\
\text { потреб і } \\
\text { планування } \\
\text { ресурсів }\end{array}$ \\
\hline $\begin{array}{l}\text { До техноцентризму - } \\
\text { первинний } \\
\text { антропоцентризм: } \\
\text { природний Гомо } \\
\text { Екологікус }\end{array}$ & $\begin{array}{l}\text { Техноцентризм: } \\
\text { зародження Гомо } \\
\text { Економікус }\end{array}$ & $\begin{array}{l}\text { Від техно- до } \\
\text { антропо- } \\
\text { центризму: } \\
\text { Гомо } \\
\text { Економікус+ } \\
\text { Гомо Соціаліс }\end{array}$ & $\begin{array}{c}\text { Антропо- } \\
\text { центризм: } \\
\text { Гомо Економікус+ } \\
\text { Гомо Соціаліс } \\
+ \text { Гомо Екологікус }\end{array}$ \\
\hline
\end{tabular}

Рис. 1. «Антропоцентризм - техноцентризм - використання природних ресурсів» у зміні фаз промислової революції

Джерело: Розроблено авторами відповідно до В. Zylman [22], Буркинський та ін. [10]

Еволюція інноваційного моделювання Helix, про що говорилося вище, - це зміна етапів і відповідних моделей (рис. 2 - на основі [7; 8; 23]):

- Triplex Helix модель: інноваційне забезпечення економіки, науки та освіти, державної діяльності;

- Quadruple Helix модель: інноваційне забезпечення економіки, науки та освіти, державної діяльності, активного соціуму та демократіі;

- Quintuple Helix модель: інноваційне забезпечення економіки, науки та освіти, державної діяльності, активного соціуму та демократії, природокористування та охорони довкілля.

Відповідно до інклюзивного підходу, інноваційність розвитку залежить не тільки від знаннєвого забезпечення економічної та екологічної сталості суспільства, а також і від «соціальних знань», а також державної та іншої регуляторної підтримки (на рис. 2 - відповідні механізми). Механізми регулювання впливають на етапи еволюції Helix моделей таким чином: Triplex Helix - 
переважно ринкове регулювання; Quadruple Helix - переважно соціальне регулювання; Quintuple Helix - переважно державне, а також соціальне регулювання [23].

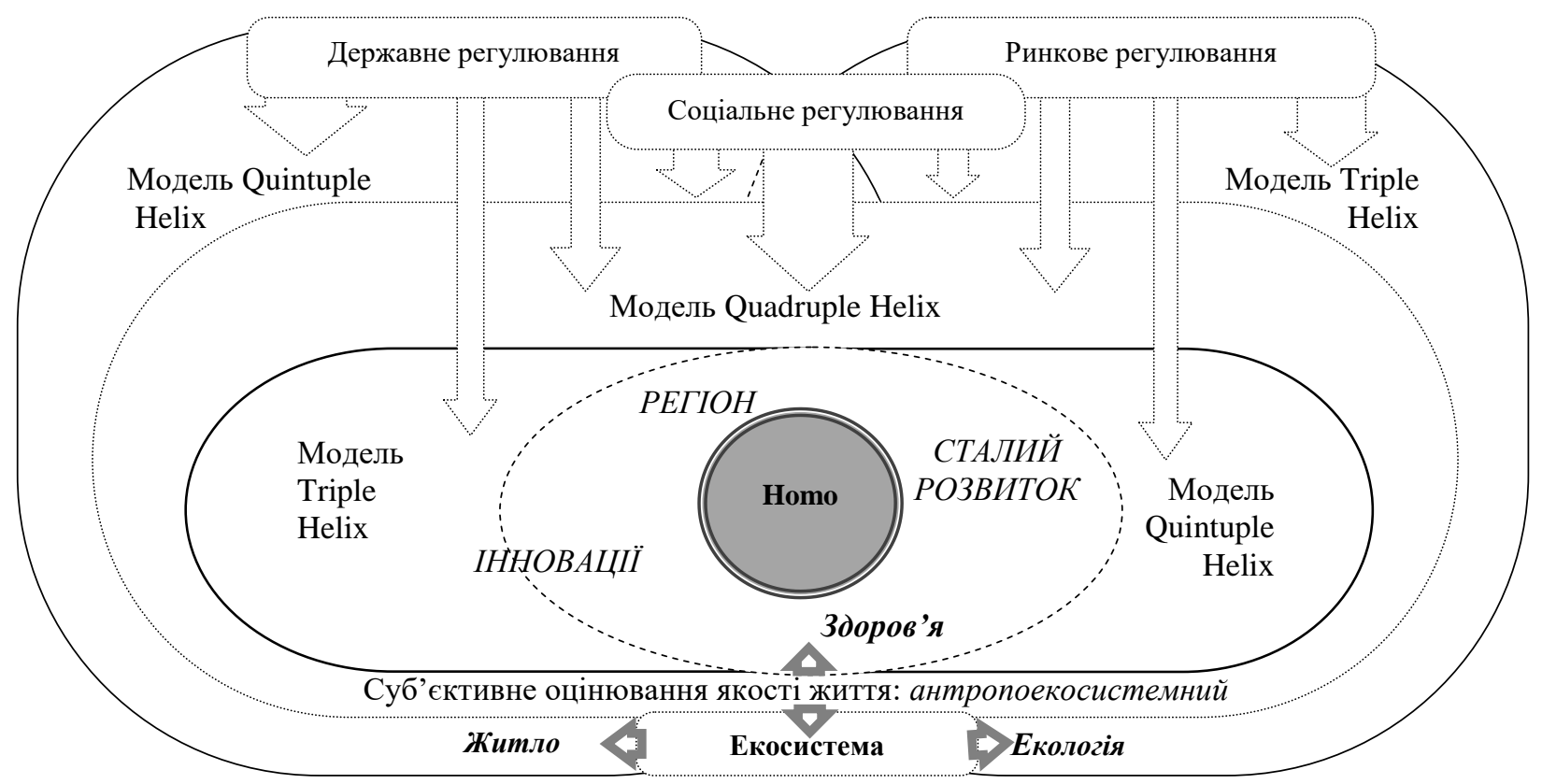

Рис. 2. Схема Helix-моделювання як основа комплексного аналізу соціальних, екологічних, інноваційних аспектів діяльності в антропоекосистемах

Джерело: розроблено авторами на основі [7; 8; 23]

Державне регулювання спрямоване на встановлення правил і стимулів інноваційної діяльності. Високий рівень розвиненості економіки потребує передусім дію механізму ринкового регулювання, що каталізує інноваційний розвиток країни в тому числі в соціальній та екологічній сферах. Поєднання та спільна дія механізмів державного, ринкового та соціального регулювання $\epsilon$ обов’язковою передумовою формування політики реалізації Цілей сталого розвитку [24].

В антропоекосистемі центральним елементом є індивід, навколо якого функціонує природне та штучно створене середовище. Для того, щоб з'ясувати, наскільки та чи інша антропоекосистема $\epsilon$ порівняно успішно функціонуючою, можна скористатися результатами суб'єктивного оцінювання думок індивідів у межах певної території, щодо якості життя - інтегрального показника, в якому враховуються різноаспектні питання. В таблицях 1-4 представлені результати порівняльнорейтингового аналізу якості життя населення економічних районів (зокрема, Причорноморського) України; за чотирма умовними групами показників: стан здоров'я та матеріальної депривації; стан житла та рекреація; інноваційність; стан екології.

Таблиця 1

Порівняльний аналіз показників стану здоров'я та матеріальної депривації за економічними районами України, 2019 р.

\begin{tabular}{|c|c|c|c|c|c|c|c|c|c|}
\hline \multirow{3}{*}{$\begin{array}{l}\text { Економічний район } \\
\\
\text { Східний }\end{array}$} & \multicolumn{8}{|c|}{ Показники / Рейтинги } & \multirow{3}{*}{$\begin{array}{c}\text { Сумарний } \\
\text { рейтинг } \\
\\
\text { VIII }\end{array}$} \\
\hline & \multicolumn{2}{|c|}{$\begin{array}{l}\text { Кількість } \\
\text { членів домо- } \\
\text { господарств, } \\
\text { які оцінили } \\
\text { свій стан } \\
\text { здоров'я як } \\
\text { добрий, тис. }\end{array}$} & \multicolumn{2}{|c|}{$\begin{array}{l}\text { Кількість } \\
\text { членів домо- } \\
\text { господарств, } \\
\text { які оцінили } \\
\text { свій стан } \\
\text { здоров'я як } \\
\text { поганий, тис. }\end{array}$} & \multicolumn{2}{|c|}{$\begin{array}{l}\text { Домогосподарства, } \\
\text { члени яких } \\
\text { постійно } \\
\text { відмовляли собі в } \\
\text { найнеобхіднішому, } \\
\text { крім харчування, } \\
\text { тис. }\end{array}$} & \multicolumn{2}{|c|}{$\begin{array}{l}\text { Частка осіб, які } \\
\text { потерпають від } \\
4 \text { і > ознак } \\
\text { матеріальної } \\
\text { депривацї̈ із } 9 \\
\text { ознак, \% }\end{array}$} & \\
\hline & 1914,42 & VII & 756,14 & VIII & 1105,30 & VIII & 17,40 & IV & \\
\hline Донецький & 1279,42 & VIII & 366,46 & I & 499,33 & I & 17,20 & III & III \\
\hline Придніпровськ & 2853,58 & III & 527,52 & VII & 874,21 & VII & 17,70 & $\mathrm{~V}$ & VI \\
\hline Причорноморський & 2465,38 & IV & 380,62 & II & $\mathbf{7 8 1 , 1 4}$ & $\mathbf{V}$ & 26,80 & VII & IV \\
\hline
\end{tabular}


Продовження табл. 1

\begin{tabular}{|l|l|l|l|l|l|l|l|l|c|}
\hline Подільський & 1937,13 & VI & 513,73 & VI & 834,22 & VI & 22,40 & VI & VII \\
\hline Центральний & 3112,25 & II & 424,49 & III & 654,30 & III & 14,90 & II & I \\
\hline Карпатський & 3636,18 & I & 486,17 & V & 732,14 & IV & 28,20 & VIII & IV \\
\hline Поліський & 2140,53 & V & 440,59 & IV & 521,29 & II & 12,10 & I & II \\
\hline
\end{tabular}

"Детальне дослідження показників соціального відторгнення у контексті моделей соціального добробуту проведено в роботі І. І. Локтєвої [25]

Джерело: Розраховано авторами на основі даних Державної служби статистики України [26]

Таблиця 2

Порівняльний аналіз показників стану житла та рекреації, 2019 р.

\begin{tabular}{|c|c|c|c|c|c|c|c|c|c|}
\hline \multirow[b]{2}{*}{ Економічний район } & \multicolumn{8}{|c|}{ Показники / Рейтинги } & \multirow[b]{2}{*}{$\begin{array}{c}\text { Сумарний } \\
\text { рейтинг }\end{array}$} \\
\hline & \multicolumn{2}{|c|}{$\begin{array}{l}\text { Частка } \\
\text { населення, яке } \\
\text { живе у } \\
\text { перенаселеному } \\
\text { житлі, \% }\end{array}$} & \multicolumn{2}{|c|}{$\begin{array}{l}\text { Частка домо- } \\
\text { господарств, } \\
\text { які (дуже) } \\
\text { незадоволені } \\
\text { житловими } \\
\text { умовами, \% }\end{array}$} & \multicolumn{2}{|c|}{$\begin{array}{l}\text { Частка домо- } \\
\text { господарств, які } \\
\text { (дуже) } \\
\text { задоволені } \\
\text { житловими } \\
\text { умовами, \% }\end{array}$} & \multicolumn{2}{|c|}{$\begin{array}{l}\text { Кількість осіб*, } \\
\text { які можуть } \\
\text { дозволити } \\
\text { мінімальні } \\
\text { рекреаційні } \\
\text { послуги, тис. }\end{array}$} & \\
\hline Східний & 46,90 & II & 14,90 & $\mathrm{~V}$ & 60,60 & $\mathrm{I}$ & 2258,60 & $\mathrm{~V}$ & I \\
\hline Донецький & 34,90 & I & 15,90 & VI & 53,50 & $\mathrm{~V}$ & 928,70 & I & I \\
\hline Придніпровський & 48,30 & IV & 12,30 & $\mathrm{I}$ & 53,80 & IV & 2365,50 & VII & IV \\
\hline Причорноморський & 48,40 & $\mathbf{V}$ & 14,60 & IV & 52,20 & IV & 1916,90 & IV & VI \\
\hline Подільський & 47,90 & III & 16,10 & VII & 49,00 & VIII & 1739,90 & III & VII \\
\hline Центральний & 54,50 & VII & 13,10 & II & 60,60 & I & 2298,80 & VI & $\mathrm{V}$ \\
\hline Карпатський & 59,80 & VIII & 18,30 & VIII & 52,20 & IV & 2978,50 & VIII & VIII \\
\hline Поліський & 52,30 & VI & 13,40 & III & 54,40 & III & 1563,00 & II & III \\
\hline
\end{tabular}

ККількість осіб, які проживають в домогосподарствах, що потерпали від недостатності коштів для проведення щороку одного тижня відпустки далеко від дому, ураховуючи перебування в іншому помешканні (садовий будинок, дача та ін.) або у друзів/родичів; тис.

Джерело: Розраховано авторами на основі даних Державної служби статистики України [26]

Таблиця 3

Порівняльний аналіз показників інноваційності, 2019 р.

\begin{tabular}{|c|c|c|c|c|c|c|c|c|c|}
\hline \multirow[b]{2}{*}{ Економічний район } & \multicolumn{8}{|c|}{ Показники / Рейтинги } & \multirow{3}{*}{$\begin{array}{l}\text { Сумарний } \\
\text { рейтинг } \\
\\
\\
\text { III }\end{array}$} \\
\hline & \multicolumn{2}{|c|}{$\begin{array}{l}\text { Кількість осіб, } \\
\text { які } \\
\text { повідомили, } \\
\text { що } \\
\text { користувалися } \\
\text { послугами } \\
\text { Інтернету не } \\
\text { менше, ніж раз } \\
\text { на день, тис. }\end{array}$} & \multicolumn{2}{|c|}{$\begin{array}{l}\text { Кількість } \\
\text { домогосподарств } \\
\text {, які мають } \\
\text { доступ до } \\
\text { Інтернету вдома, } \\
\text { тис. }\end{array}$} & \multicolumn{2}{|c|}{$\begin{array}{l}\text { Частка } \\
\text { населення, } \\
\text { яке має } \\
\text { повну вищу } \\
\text { освіту, \% }\end{array}$} & \multicolumn{2}{|c|}{$\begin{array}{l}\text { Кількість осіб, які } \\
\text { проживають в } \\
\text { домо- } \\
\text { господарствах, що } \\
\text { не мали } \\
\text { можливості } \\
\text { дозволити собі } \\
\text { неочікувані } \\
\text { необхідні витрати, } \\
\text { тис. }\end{array}$} & \\
\hline Східний & 2557,10 & IV & 1325,60 & III & 25,80 & II & 2616,70 & $\mathrm{~V}$ & \\
\hline Донецький & 1225,30 & VIII & 698,10 & VIII & 15,10 & VIII & 1455,40 & I & VIII \\
\hline Придніпровський & 2989,20 & $\mathrm{I}$ & 1719,10 & $\mathrm{I}$ & 23,50 & III & 2896,70 & VII & II \\
\hline Причорноморський & 2367,00 & $\mathbf{V}$ & 1037,70 & $\mathbf{V}$ & 22,60 & IV & 2402,20 & IV & IV \\
\hline Подільський & 1462,10 & VII & 774,80 & VII & 19,00 & VI & 2191,30 & III & VII \\
\hline Центральний & 2952,60 & II & 1553,00 & II & 33,80 & I & 2861,50 & VI & I \\
\hline Карпатський & 2781,30 & III & 1230,50 & IV & 19,80 & $\mathrm{~V}$ & 3159,90 & VIII & $\mathrm{V}$ \\
\hline Поліський & 1774,50 & VI & 842,70 & VI & 17,60 & VII & 1994,90 & II & VI \\
\hline
\end{tabular}

Джерело: Розраховано авторами на основі даних Державної служби статистики України [26] 
Порівняльний аналіз усередненого показника стану екології, 2019 р.

\begin{tabular}{|c|c|c|c|}
\hline Економічний район & Показник* & Рейтинг & $\begin{array}{l}\text { Сумарний } \\
\text { рейтинг }\end{array}$ \\
\hline Східний (Сумська, Полтавська, Харківська області) & 17,67 & VII & IV \\
\hline Донецький (Донецька, Луганська обл.) & 14,00 & $\mathrm{~V}$ & III \\
\hline $\begin{array}{l}\text { Придніпровський (Дніпропетровська, Запорізька, Кіровоградська } \\
\text { обл.) }\end{array}$ & 20,33 & VIII & VII \\
\hline Причорноморський (Одеська, Херсонська, Миколаївська обл.) & 16,67 & VI & VI \\
\hline Подільський (Тернопільська, Хмельницька, Винницька обл.) & 10,00 & III & VIII \\
\hline Центральний (м. Київ, Київська, Черкаська обл.) & 10,00 & III & $\mathrm{I}$ \\
\hline $\begin{array}{l}\text { Карпатський (Закарпатська, Львівська, І-Франківська, Чернівецька } \\
\text { обл.) }\end{array}$ & 9,25 & II & IV \\
\hline Поліський (Волинська, Рівненська, Житомирська, Чернігівська обл.) & 5,25 & I & II \\
\hline
\end{tabular}

*Середнє арифметичне міст за станом екології в них, за областями економічних районів

*** Вагові коефіцієнти 4-х груп показників (відповідно до представлених таблиць) рівні

Джерело: Розраховано авторами на основі даних у дослідженні А. Батурина та ін. [27]

Результати порівняльно-рейтингового аналізу є невтішними для населення Причорноморського економічного району. Унікальні не тільки для України умови для життя, бізнесу та міжнародної діяльності використовуються неефективно. Передусім, йдеться про рекреаційно-туристичний потенціал Українського Причорномор'я.

За умови пріоритезації інвестування оздоровчої рекреації та туризму [28], як це існує в таких європейських країнах, як Азербайджан, Болгарія, Хорватія, Естонія, Фінляндія, Грузія, Угорщина, Литва, Чорногорія, Польща, Румунія, Сербія, Словаччина, Словенія, Швейцарія, Туреччина, Україна може приєднатися до загальносвітової тенденції стрімкого зростання досліджуваної сфери: Європа 2017 - 210.8 US\$ млрд., оптимістичний прогноз 2022 (прогноз складено до настання пандемічної кризи COVID-19) - 275.0 US\$ млрд. (Global Wellness Institute (2018) [29]).

Рекреаційний сектор національної економіки має тісні галузеві та територіальні зв'язки 3 курортно-лікувальним і туристичним комплексами. В контексті синергетичної взаємодії та протидію економіко-екологічним конфліктам у сфері туристично-рекреаційної діяльності доцільно підтримувати розвиток так званих «зелених» форм рекреації та туризму, а саме [30]:

-захист зон відвідання та відпочинку від понаднормового екологічного навантаження. Необхідне попереднє оцінювання асиміляційного потенціалу рекреаційних територій, порушення якого призводить до деградації рекреаційного середовища та економіко-екологічних збитків;

- регулювання туристичного та рекреаційного попиту на природні рекреаційні ресурси, зокрема, рекреаційні зони природно-заповідного фонду: більший попит означає додаткові надходження в економіку місця призначення, проте зі зростанням кількості туристів підвищується ймовірність виникнення екологічних і соціальних конфліктів;

- всебічна підтримка розвитку та поширення «зеленого» (сільського) туризму як форми малого підприємництва та відновлення життя в сільській місцевості: локальний характер та індивідуальний підхід до задоволення рекреаційних і туристичних потреб усуває наведені у попередньому пункті потенційні конфліктні ситуації, спричинені поведінкою туристів;

-інклюзивний підхід до розгортання на загальнонаціональному та регіональному рівнях стійкого (збалансованого) туризму та рекреації, з метою створення поряд із економічним також соціального та екологічного ефектів від інноваційного розвитку рекреаційно-туристичної діяльності відповідно до Цілей сталого розвитку 2030.

Економічний результат - рекреаційно-туристичний продукт - на територіальному рівні можна зобразити у вигляді схеми (рис. 3), в основу побудови якої було покладено принципи, викладені в роботах [30-34].

Так, згідно принципів «концепції ринків» [32, с. 43-45], ринок рекреаційних послуг (рис. 3) утворюють всі реальні та потенційні споживачі з рекреаційними потребами, для задоволення яких вони бажають або готові прийняти участь в створенні рекреаційно-туристичного продукту. 


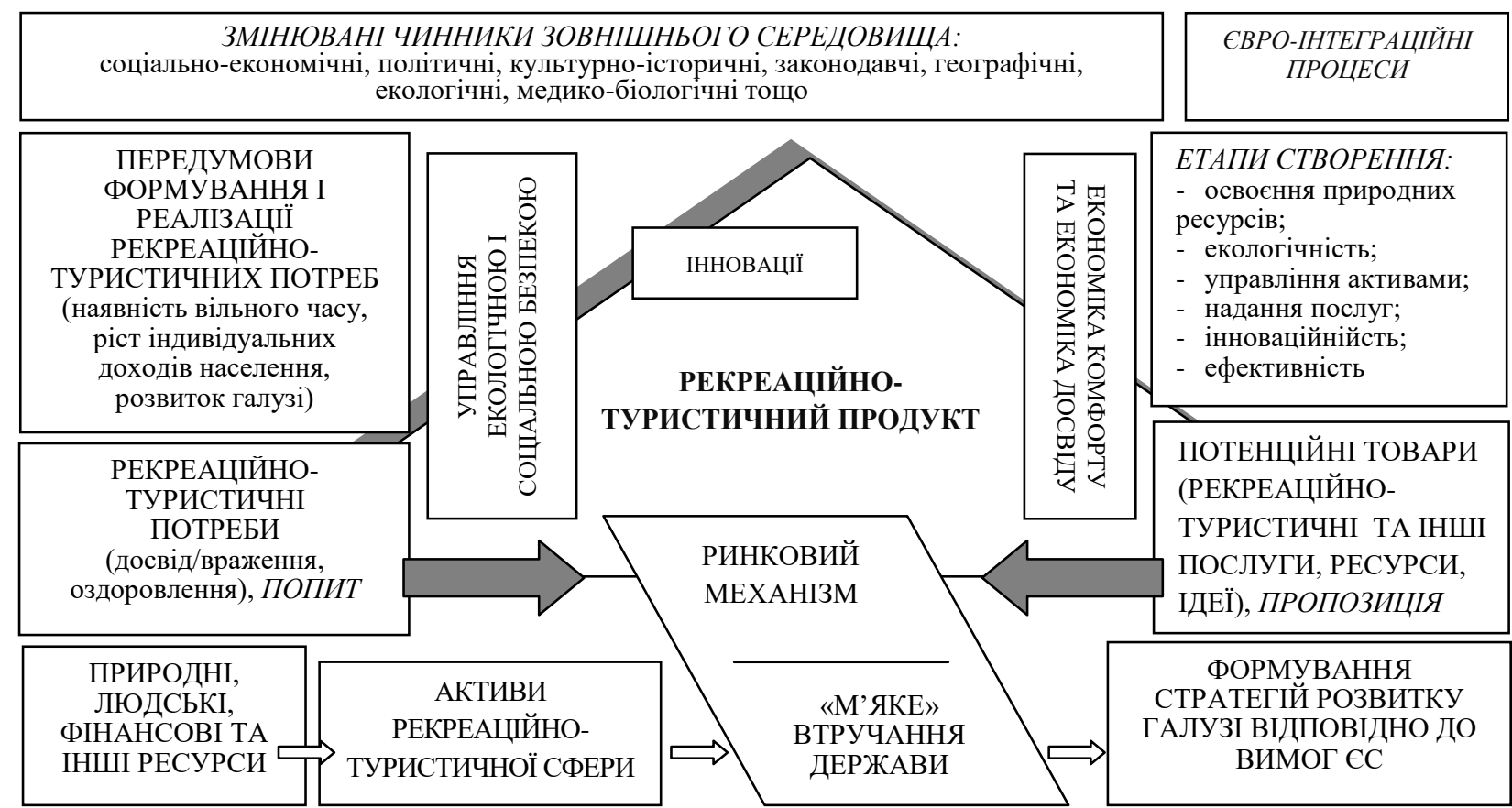

Рис. 3. Формування рекреаційно-туристичного продукту - економічного результату відповідної галузі та основного напряму розвитку економіки досвіду

Джерело: розроблено авторами на основі [30-34]

Поряд із інклюзивним ринковий підхід до формування рекреаційно-туристичного продукту забезпечує балансуванні інтересів рекреаційно-туристичної галузі та таких ринків:

- ринок рекреаційних ресурсів (як частина ринку природних ресурсів);

- ринок виробників рекреаційно-туристичного продукту;

- ринок посередників, передусім, турагентів;

- ринок держави: територіальні органи та уряд використовують кошти, отримані у формі податків, зборів і штрафів і спрямовують їх за цільовим призначенням на рекреацію.

Цінність у рекреаційно-туристичній сфері, як правило, асоціюється з поняттям комфорту, що в умовах пандемічної кризи набуває особливого значення. У роботі [35] розглядаються різні аспекти рекреаційного комфорту: інформаційний, економічний, естетичний, побутовий, психологічний.

Серед основних передумов виробництва якісного та безпечного рекреаційно-туристичного продукту слід назвати такі:

- максимальна відповідність послуг вимогам споживачів; гнучкість рекреаційного сервісу;

- оптимізація організаційної структури управління рекреаційних підприємств;

- «інклюзія» та екологізація процесу рекреаційної діяльності на всіх його етапах;

- безпека туризму та рекреації - в умовах пандемічної кризи набуває першочергового значення;

- забезпечення комфорту як атрибуту добробуту, актуалізованого в результаті необхідності знаходження вдома (через небезпеку COVID-19); концептуально пов'язано з поняттям «якості життя» [36]: здоров'я, сімейне та громадське життя, матеріальне благополуччя, політична стабільність і безпека, клімат і географія.

Розвиток рекреації та туризму за міжнародними стандартами є невід'ємною складовою євроінтеграційних процесів України - табл. 5.

Для ефективної реалізації Стратегії розвитку туризму та курортів на період до 2026 року [39], на наш погляд, необхідно адаптувати деякі положення Програми [41] для обгрунтування розвитку рекреаційно-туристичної галузі України, передусім, в межах Причорноморського економічного району. Доцільність такої адаптації пояснюється передусім рекреаційною орієнтованістю Програми. 
Свроінтеграція туризму в Україні в контексті економічного та галузевого співробітництва*

\begin{tabular}{|c|c|}
\hline Діючі положення & Уточнення до діючих положень і пропозиції \\
\hline $\begin{array}{l}\text { Стаття } 399 \\
\text { Сторони співробітничають у галузі } \\
\text { туризму з метою зміцнення розвитку } \\
\text { конкурентоспроможної туристичної } \\
\text { галузі як генератора економічного } \\
\text { зростання і стимулювання економіки, } \\
\text { зайнятості та валютних надходжень. }\end{array}$ & $\begin{array}{l}\text { Відповідальні органи в Україні: } \\
\text { з } 2020 \text { р. Міністерство культури та інформаційної політики України. } \\
\text { Для посилення ролі туризму як генератора економічного зростання } \\
\text { необхідна відповідальність на рівні Міністерства розвитку } \\
\text { економіки, торгівлі та сільського господарства України. } \\
\text { Станом на } 2020 \text { р. необхідна розробка механізму сумісної } \\
\text { відповідальності в сфері туризму між цими Міністерствами }\end{array}$ \\
\hline $\begin{array}{l}\text { Стаття } 400 \\
\text { 1. Співробітництво на } \\
\text { двосторонньому, регіональному та } \\
\text { європейському рівнях } \\
\text { грунтуватиметься на таких } \\
\text { принципах: } \\
\text { а) повага самобутності та інтересів } \\
\text { місцевих громад, особливо у сільській } \\
\text { місцевості; } \\
\text { b) важливість культурної спадщини; } \\
\text { с) чітка взаємодія між туризмом та } \\
\text { захистом навколишнього середовища. }\end{array}$ & $\begin{array}{l}\text { d) забезпечення безпеки туристів у відповідності до європейських } \\
\text { стандартів } \\
\text { Розробка комплексних програм розвитку сільського (зеленого) та } \\
\text { екологічного туризму та відновлення культурної спадщини на } \\
\text { територіях місцевих громад в Україні } \\
\text { Гармонізація в сфері туризму національних стандартів України з } \\
\text { міжнародними та європейськими нормативними документами, а } \\
\text { саме системи ISO 22300 “Безпека і стійкість до негативних } \\
\text { зовнішніх впливів”: } \\
\text { ISO } 22301 \text { - Системи менеджменту безперервності бізнесу; } \\
\text { ISO } 22395 \text { - Стійкість спільноти до негативних зовнішніх впливів; } \\
\text { ISO } 22320 \text { - Менеджмент надзвичайних ситуацій; } \\
\text { ISO } 22316 \text { - Стійкість організації. }\end{array}$ \\
\hline $\begin{array}{l}\text { Стаття } 401 \\
\text { Співробітництво зосереджується на } \\
\text { напрямах: } \\
\text { a) обмін досвідом; } \\
\text { b) стратегічне партнерство; } \\
\text { с) просування та розвиток продуктів і } \\
\text { ринків; } \\
\text { d) ефективні стратегії; } \\
\text { е) навчання спеціалістів; } \\
\text { f) розвиток і сприяння туризму на } \\
\text { основі місцевих громад. }\end{array}$ & $\begin{array}{l}\text { Станом на } 2020 \text { р. пріоритет обміну досвідом із боротьби з } \\
\text { наслідками пандемії COVID-19 } \\
\text { g) розвиток комплексних туристичних продуктів, які дозволяють } \\
\text { задовольняти рекреаційні, оздоровчі та лікувальні потреби туристів }\end{array}$ \\
\hline
\end{tabular}

Розділ V, Глава 16 [37]

Джерело: Розроблено авторами на основі [37-40]

Отже, в Українському Причорномор’ї необхідно створити сучасний високоефективний i конкурентоспроможний рекреаційний комплекс, який здатен задовольняти потреби населення в якісних і безпечних санаторно-курортних і туристичних послугах, а саме:

- сприятливі умови для розвитку матеріально-технічної бази санаторно-курортного i туристичного комплексу, засобів розміщення та інфраструктури;

- збереження, розвиток, ефективне та екологічно безпечне використання природних, культурних і антропогенних рекреаційних ресурсів;

- сталий інклюзивний розвиток рекреаційного комплексу;

- стимулювання суб'єктів рекреаційно-туристичної діяльності до формування внутрішнього ринку відповідних послуг;

- створення нових робочих місць у санаторно-курортній і туристичній сфері, стимулювання професіоналізму персоналу;

- інтеграція регіону Українського Причорномор'я в систему світового туристичного ринку;

- розвиток наукових досліджень у сфері курортів i туризму, рекреаційного природокористування, економіки досвіду та інклюзивного розвитку.

Серед пріоритетних напрямів інвестування слід виокремити такі:

- нове будівництво та завершення будівництва об'єктів санаторно-курортного і туристичного призначення;

- завершення будівництва та реконструкція об’єктів та мереж водопостачання і каналізування, берегоукріплення, проведення протизсувних робіт; 
- інноваційний та інклюзивний розвиток, ефективне використання і екологічний моніторинг рекреаційних ресурсів та територій.

Висновки та перспективи подальших досліджень. В результаті проведеного дослідження обІрунтовані та узагальнені аспекти інноваційного моделювання систем, що мають елементи економічного, соціального та екологічного розвитку в умовах Industry 4.0. Дослідження антропоекосистем $\epsilon$ реагуванням на загострення стану навколишнього середовища, спричиненого поєднанням соціально-економічної нестабільності та наслідків впливу пандемії коронавірусу на життя країни, регіону та індивіда. В роботі проведений порівняльно-рейтинговий аналіз показників суб'єктивного оцінювання населення економічний районів, зокрема, Причорноморського економічного району, що дозволяє сформувати первинне бачення щодо антропоекосистем, які формуються в Україні. Розглянуті положення щодо розвитку рекреації та туризму, інноваційність яких спрямована на подолання наслідків пандемії коронавірусу та євроінтеграції України. Запропоновані уточнення до діючих положень і пропозиції щодо євроінтеграції туристичної галузі України, зокрема, щодо гармонізації в сфері туризму національних стандартів України 3 міжнародними та європейськими нормативними документами, а саме системи ISO 22300 "Безпека і стійкість до негативних зовнішніх впливів".

У подальшому необхідні науково-прикладні розробки механізмів регулювання інноваційної діяльності в соціально-економічних системах України.

\section{ЛІТЕРАТУРА}

1. Преображенский В. С., Райх Е. Л. Проблемы экологии человека и география // Теория и методика географических исследований экологии человека. Москва: ИГ РАН, 1974. С. 12-22.

2. Sustainable development at the Black Sea / European MSP Platform. 2019. Bucharest. URL: https://www.msp-platform.eu/events/sustainable-development-black-sea

3. Ibarra D., Ganzarain J., Igatua J. I. Business model innovation through Industry 4.0: A review // Procedia Manufacturing. 2018, 22. P. 4-10. https://doi.org/10.1016/j.promfg.2018.03.002

4. Kalogeras A. P., Anagnostopoulos C. Innovation modelling: Understanding the fundamentals of the transformation of research to innovation // Proceedings of the $1^{\text {st }}$ IFAC Conference on Embedded Systems, Computational Intelligence and Telematics in Control - CESCIT 2012. Wuerzburg, 2012. P. 182-187. https://doi.org/10.3182/20120403-3-DE-3010.00053

5. Tidd J. A review of innovation models: Technical Report, 2006. https://doi.org/10.13140/RG.2.2.30295.57762

6. Walrave B., Raven R. Modelling the dynamics of technological innovation systems // Research Policy. 2016. 45(9). P. 1833-1844. https://doi.org/10.1016/j.respol.2016.05.011

7. Carayannis E. G., Campbell D. F. J. Triple Helix, Quadruple Helix and Quintuple Helix and how do knowledge, innovation and the environment relate to each other? : A proposed framework for a transdisciplinary analysis of sustainable development and social ecology // International journal of social ecology and sustainable development, 2010. 1(1). C. 41-69.

8. Carayannis E. G., Barth T. D., Campbell D. F. The Quintuple Helix innovation model: global warming as a challenge and driver for innovation. Journal of innovation and entrepreneurship. 2012. 1(2). https://doi.org/10.1186/2192-5372-1-2.

9. Буркинський Б. В., Хумарова Н. І. Інноваційний імператив становлення «зеленої» економіки // Природно-ресурсний потенціал збалансованого (сталого) розвитку Украӥни: міжнародна науковопрактична конференція, Киї, $19-21$ квітня 2011 р., матеріали VII міжнародного бізнес форуму (Київ, 21 квітня 2011 р.): у 2 т. Київ: Центр екологічної освіти та інформації, 2011. Т. 2. С. 359-363.

10. Буркинський Б. В., Хумарова Н. І., Шевченко Г. М. Деякі аспекти державного управління природними активами в Україні. Економічні інновації. 2020. 22(1(74). С. 8-19. https://doi.org/10.31520/ei.2020.22.1(74).8-19

11. Хумарова Н. I. Екологічні цільові програми у системі державного регулювання природокористування / Екологізація економіки як інструмент сталого розвитку в умовах конкурентного середовища. Львів: НЛТУУ, 2005. Вип. 15. С. 187-194.

12. Грищенко В. Ф., Грищенко I. В., Ашхаб Х. Х. Вплив несвоєчасності прийняття рішень у сфері управління національним господарством на економіку України // Електронне наукове фахове видання «Економіка та суспільство». 2018. Вип. 17. С. 98-106. https://doi.org/32782/2524-0072/2018$17-14$ 
13. Грищенко В. Ф., Грищенко І. В., Самофалова О. А. Безпека підприємницької діяльності як складова національної безпеки держави // Державне управління: удосконалення та розвиток. 2015. №12. URL: http://www.dy.nayka.com.ua/pdf/12_2015/5.pdf

14. Грищенко I. В. Еколого-економічні загрози та небезпеки в Україні: проблеми ідентифікації та протидії // Економіка ma держава. 2012. №3. C. 47-51. URL: http://www.economy.in.ua/pdf/3_2012/15.pdf

15. Грищенко I. В. Управління експортно-імпортним потенціалом регіону з урахуванням вимог екологічної безпеки як фактор гарантування сталого розвитку // Інвестиції практика та досвід. 2012. №1. С. 71-74.

16. Кислий В. М., Шевченко Г. М. Аналіз передумов формування ринку рекреаційних послуг в Україні // Механізм регулювання економіки. 2007. №2. С. 27-36.

17. Кислий В. М., Шевченко Г. М. Роль та місце природно-рекреаційної сфери в системі територіально-економічних відносин // Екологічний менеджмент у загальній системі управління : тези VII щоріч. Всеукр. наук. конф. (м. Суми, 24-25 квітня 2007 р.). Суми : СумДУ, 2007. С. 31-34.

18. Shevchenko, H. M., Ivanova, T. E. Innovative-marketing directions of recreational-tourism industry in Ukraine // Economic processes management : International scientific e-journal. 2015. №3. URL: https://essuir.sumdu.edu.ua/handle/123456789/42355?mode=full

19. Shevchenko H. M., Pakhomov V. M., Petrushenko M. M. Economic and legal issues of rural and recreational land use in Ukraine // Economic Annals-XXI. 2016. 1-2(156). P. 54-58. https://doi.org/10.21003/ea.V156-0012.

20. Шевченко Г. М. Прогнозування розвитку рекреації в Україні : соціально-економічний еквілібріум : монографія / Г. М. Шевченко. Суми : Університетська книга, 2017. 336 с.

21. Shevchenko H. M. Regulatory policy and optimization of investment resource allocation in model of functioning recreation industry // Baltic journal of economic science. 2017. 3(1). P. 109-115. http://dx.doi.org/10.30525/2256-0742/2017-3-1-109-115.

22. Zylman B. Industry 4.0 and Beyond to 6.0. 2017. URL: https://www.bzylman.com/singlepost/2016/05/08/Your-daily-dose-of-design

23. Петрушенко М. М. Еволюція інноваційної моделі Quintuple Helix на прикладі промислових і природних парків України // Вісник економічної науки Украӥни. 2020. №1(38). С. 109-115. https://doi.org/10.37405/1729-7206.2020.1(38).109-115

24. Про Цілі сталого розвитку України на період до 2030 року / Указ Президента України від 30.09.2019. URL: https://zakon.rada.gov.ua/laws/show/722/2Б019

25. Локтєва I. I. Соціальне відторгнення у контексті моделей соціального добробуту: міжнародне порівняння // Украӥнський соціум. 2016. №1(56). С. 19-27

26. Державна служба статистики України / Доходи та умови життя. URL: http://www.ukrstat.gov.ua/

27. Батурин А., Бондарь М., Ковальчук Г., Королева Е., Купновицкая У. Рейтинг экологической безопасности регионов. Где в Украине самый чистый воздух // Фокус. 31 янв. 2020. URL: https://focus.ua/ukraine/449254-reiting_ekologicheskoi_bezopasnosti_regionov_gde_v_ukraine_samyi _chistyi_vozdukh

28. Petrushenko M., Shevchenko H., Burkynskyi B., Khumarova N. Game-theoretic model of investment in inclusive wellness and recreation by regions in Ukraine // Investment Management and Financial Innovations, 2019. №16(4.). P. 382-394. http://dx.doi.org/10.21511/imfi.16(4).2019.32

29. Global Wellness Institute / Global wellness tourism economy. 2018. URL: https:// globalwellnessinstitute.org/wp-content/uploads/2018/11/GWI_GlobalWellnessTourismEconomyReport.pdf

30. Шевченко Г.М. Організаційно-економічний механізм формування та використання природно-рекреаційного потенціалу території : дис. ... канд. екон. наук. / Г.М. Шевченко. Суми, 2007. $216 \mathrm{c}$.

31. Балабанов И. Т., Балабанов А. И. Экономика туризма: учеб. пособие. Москва: Финансы и статистика, 2002. $176 \mathrm{c.}$

32. Котлер Ф. Маркетинг менеджмент. Санкт-Петербург: Питер Ком, 1999. 896 с.

33. Серебренников И.В. Формирование организационно-экономического механизма развития курортно-туристской отрасли (на примере города-курорта Сочи): автореф. дис. на соиск. учен. степени канд. экон. наук: спец. 08.00.05 «Экономика и управление нар. хозяйством». СанктПетербург, 2000. 19 с.

34. Экономический потенциал административных и производственных систем: [монография / под общей ред. О.Ф. Балацкого]. Сумы: ИТД «Университетская книга», 2006. 973 с. 
35. Нориганова О. А. Методология оценки туристической услуги как рыночной категории // Актуальні проблеми економіки. 2003. №2(13). С. 37-42.

36. World Happiness Report 2016 [Electronic resource] / [edit. by J. Helliwell, R. Layard, J. Sachs]. New York : Sustainable Development Solutions Network. Vol. I. 65 p. URL: http://worldhappiness.report/wp-content/uploads/sites/2/2016/03/HR-V1_web.pdf.

37. Association Agreement between the European Union and its Member States, of the one part, and Ukraine, of the other part // Official Journal of the European Union. OJ L 161, 29.5.2014. P. 3-2137. URL: https://eur-lex.europa.eu/legal-content/EN/ALL/?uri=CELEX\%3A22014A0529\%2801\%29

38. Свроінтеграційний портал / Туризм. 27.09.2017. URL: http://eu-ua.org/yevrointehratsiia/turyzm

39. Стратегія розвитку туризму та курортів на період до 2026 року. Постанова КМУ №168-р від 16.03.2017. URL: https://zakon.rada.gov.ua/laws/show/168-2017-\%D1\%80\#Text

40. ISO. COVID-19 response: freely available ISO standart, 2020. URL: https://www.iso.org/covid19

41. Програма розвитку Криму як цілорічного загальнодержавного та міжнародного курортнорекреаційного i туристичного центру / Постанова КМУ №133 від 29.01.2003. URL: https://zakon.rada.gov.ua/laws/show/133-2003-\%D0\%BF\#Text

\section{REFERENCES}

1. Preobrazhenskij, V. S., \& Raikh, E. L. (1974). Problemy ekologii cheloveka I geografia [Problems of human ecology and geography]. Teoria i metodika geograficheskikh issledovanij ekologii cheloveka. Moscow: IG RAN, 12-22 [in Russian].

2. Sustainable development at the Black Sea (2019). European MSP Platform. Bucharest. Retrieved from: https://www.msp-platform.eu/events/sustainable-development-black-sea

3. Ibarra, D., Ganzarain, J., \& Igatua, J. I. (2018). Business model innovation through Industry 4.0: A review. Procedia Manufacturing, 22, 4-10. https://doi.org/10.1016/j.promfg.2018.03.002

4. Kalogeras, A. P., \& Anagnostopoulos, C. (2012). Innovation modelling: Understanding the fundamentals of the transformation of research to innovation. Proceedings of the $1^{\text {st }}$ IFAC Conference on Embedded Systems, Computational Intelligence and Telematics in Control - CESCIT 2012. Wuerzburg, 182187. https://doi.org/10.3182/20120403-3-DE-3010.00053

5. Tidd, J. (2006). A review of innovation models: Technical Report. https://doi.org/10.13140/RG.2.2.30295.57762

6. Walrave, B., \& Raven, R. (2016). Modelling the dynamics of technological innovation systems. Research Policy, 45(9), 1833-1844. https://doi.org/10.1016/j.respol.2016.05.011

7. Carayannis, E. G., Campbell, D. F. J. (2010). Triple Helix, Quadruple Helix and Quintuple Helix and how do knowledge, innovation and the environment relate to each other? : A proposed framework for a trans-disciplinary analysis of sustainable development and social ecology. International journal of social ecology and sustainable development, 1(1), 41-69.

8. Carayannis, E. G., Barth, T. D. \& Campbell, D. F. (2012). The Quintuple Helix innovation model: global warming as a challenge and driver for innovation. Journal of innovation and entrepreneurship, 1(2). https://doi.org/10.1186/2192-5372-1-2

9. Burkynskyi, B. V., \& Khumarova, N. I. (2011). Innovatsiynyi imperatyv stanovlennia „zelenoi“ ekonomiky [Innovation imperative of becoming „green“ economy]. Materialy VII mizhnarodnogo biznes forumu: Pryrodno-resursnyi potentsial zbalansovanogo (stalogo) rozvytku, Kyiv, 359-363 [in Ukrainian].

10. Burkynskyi, B., Khumarova, N., \& Shevchenko, H. (2020). Deiaki aspekty derzhavnoho upravlinnia pryrodnymy aktyvamy $\mathrm{v}$ Ukrayni [Some aspects of state management of natural assets in Ukraine] Economical Innovations, 22(1(74), 8-19. https://doi.org/10.31520/ei.2020.22.1(74).8-19 [in Ukrainian].

11. Khumarova, N. I. (2005). Ekologichni tsilovi programy u systemi derzhavnogo reguliuvannia pryrodokorystuvanniam [Environmental target programs in the system of state regulation of nature management]. Ekologizatsia ekonomiky yak instrument stalogo rozvytku $v$ umovah konkurentnogo seredovyshcha. Lviv, 15, 187-194 [in Ukrainian].

12. Gryshchenko, V., Gryshchenko, I., \& Ashkhab, H. H. (2018). Vplyv nesvoiechasnosti pryiniattia rishen u sferi upravlinnia natsionalnym hospodarstvom na ekonomiku Ukrainy [The impact of untimely decision-making in a field of national economy management on the economy of Ukraine]. Economy and Society, 17, 98-106. https://doi.org/32782/2524-0072/2018-17-14

13. Gryshchenko, V. F., Gryshchenko, I. V., \& Samofalova, O. A. (2015). Security of entrepreneurship as a component of the national security of a state. Derzhavneupravlinnya: udoskonalennya ta rozvytok. 12. Retrieved from: http://www.dy.nayka.com.ua/pdf/12_2015/5.pdf [in Ukrainian]. 
14. Gryshchenko, I. (2012). Ekoloho-ekonomichni zahrozy ta nebezpeky v Ukraini: problem identyfikatsii ta protydii [Ecological and economic threats and dangers in Ukraine: problems of identification and counteraction]. Ekonomika ta derzhava, 3, 47-51. Retrieved from: http://www.economy.in.ua/pdf/3_2012/15.pdf [in Ukrainian].

15. Gryshchenko, I. (2012). Upravlinnia eksportno-importnym potentsialom rehionu z urakhuvanniam vymoh ekolohichnoi bezpeky yak factor harantuvannia staloho rozvytku [Management of export-import potential of the region taking into account the requirements of environmental safety as a factor in ensuring of sustainable development]. Investytsiyi: praktyka ta dosvid, 1, 71-74.

16. Kyslyi, V. M., \& Shevchenko, H. M. (2007). Analiz peredumov formunannya rynku rekreatsiynykh posluh $\mathrm{v}$ Ukrayni [Analysis of the preconditions for the formation of recreational services market in Ukraine]. Mekhanizm rehuliuvannia ekonomiky, 2, 27-36 [in Ukrainian].

17. Kyslyi, V. M., \& Shevchenko, H. M. (2007). Rol ta mistse pryrodno-rekreatsiinoi sfery v systemi terytorialno-ekonomichnykh vidnosyn [The role and place of the natural-recreational sphere in the system of territorial-economic relations]. Ekolohichnyi menedzhment u zahalnii systemi upravlinnia. Sumy: SumDU, 31-34 [in Ukrainian].

18. Shevchenko H. M., \& Ivanova T. E. (2015). Innovative-marketing directions of recreationaltourism industry in Ukraine // Economic processes management : International scientific e-journal, 3. Retrieved from: https://essuir.sumdu.edu.ua/handle/123456789/42355?mode=full

19. Shevchenko, H. M., Pakhomov, V. M., \& Petrushenko, M. M. (2016). Economic and legal issues of rural and recreational land use in Ukraine. Economic Annals-XXI, 1-2(156), 54-58. https://doi.org/10.21003/ea.V156-0012

20. Shevchenko H. M. (2017). Prognozuvannja rozvytku rekreacii v Ukraine: socioal'noekonomichnyjy ejkvilibrium: monografija [Forecasting of recreation development in Ukraine: socioeconomic equilibrium: monograph]. Sumy : VTD "Universytetska knyha" [in Ukrainian].

21. Shevchenko, H. M. (2017). Regulatory policy and optimization of investment resource allocation in model of functioning recreation industry. Baltic journal of economic science, 3(1), 109-115. http://dx.doi.org/10.30525/2256-0742/2017-3-1-109-115

22. Zylman, B. (2017). Industry 4.0 and Beyond to 6.0. Retrieved from: https://www.bzylman.com/single-post/2016/05/08/Your-daily-dose-of-design

23. Petrushenko, M. M. (2020). Evolyutsia innovatsiynoy modeli Quintuple Helix na prykladi promyslovykh i pryrodnykh parkiv Ukrayny [Evolution of the innovative Quintuple Helix model on the example of industrial and natural parks of Ukraine]. Visnyk ekonomichnoy nauky Ukrayny, 1(38), 109-115. https://doi.org/10.37405/1729-7206.2020.1(38).109-115 [in Ukrainian].

24. Pro Tsili staloho rozvytku Ukrayny na period do 2030 roku [On the Sustainable Development Goals of Ukraine until 2030] (2019). Ukaz Prezydenta Ukrayny vid 30.09.2019. Retrieved from: https://zakon.rada.gov.ua/laws/show/722/2019 [in Ukrainian].

25. Loktyeva, I. I. (2016). Sotsialne vidtorhnennya u konteksti modeley sotsialnoho dobrobutu: mizhnarodne porivnyannya [Social rejection in the context of models of social welfare: an international comparison]. Ukraynskyy sotsium, 1(56), 19-27 [in Ukrainian].

26. Derzhavna sluzhba statystyky Ukrayny (2019). Dokhody ta umovy zhyttya [Income and living conditions]. Retrieved from: http://www.ukrstat.gov.ua/ [in Ukrainian].

27. Baturin, A., Bondar, M., Kovalchuk, G., Koroliova, E., \& Kupnovitskaia, U. (2020). Reiting ekologicheskoy bezopasnosti regionov. Gde v Ukraine samyy chistyy vozdukh [Rating of ecological safety of regions. Where is the cleanest air in Ukraine?]. Fokus, 31.01.2020. Retrieved from: https://focus.ua/ukraine/449254-reiting_ekologicheskoi_bezopasnosti_regionov_gde_v_ukraine_samyi_ chistyi_vozdukh [in Russian].

28. Petrushenko, M., Shevchenko, H., Burkynskyi, B., \& Khumarova, N. (2019). Game-theoretic model of investment in inclusive wellness and recreation by regions in Ukraine. Investment Management and Financial Innovations, 16(4.), 382-394. http://dx.doi.org/10.21511/imfi.16(4).2019.32.

29. Global Wellness Institute (2018). Global wellness tourism economy. 2018. Retrieved from: https://globalwellnessinstitute.org/wp-content/uploads/2018/11/GWI_GlobalWellnessTourismEconomy Report.pdf.

30. Shevchenko, H. M. (2007). Orhanizatsiyno-ekonomichnyy mekhanizm formuvannya ta vukorystannya pryrodno-rekreatsiynoho potentsialu terytoriy [Organizational and economic mechanism of formation and use of natural and recreational potential of the territory: dis. ... Cand. econ. Science], Sumy [in Ukrainian]. 
31. Balabanov, I. T., \& Balabanov, A. I. (2002). Ekonomika turizma [Tourism Economics: textbook]. Moscow: Finansy i statistika [in Russian].

32. Kotler, F. (1999). Marketing Management. Sankt-Peterburg: Piter Kom.

33. Serebrennikov, I. V. (2000). Formirovanie organizatsionno-ekonomicheskogo mekanizma razvitia kurortno-turistskoy otrasli (na primere goroda-kurorta Sochi) [Formation of an organizational and economic mechanism for the development of the resort and tourism industry (on the example of the resort city of Sochi): author. dis. for a degree of Cand. econom. Sciences: spec. 08.00.05 "Economy and management"]. Sankt-Peterburg [in Russian].

34. Ekonomicheskiy potenzial administrativnykh i proizvodstvennykh system [Economic potential of administrative and production systems; ed. O. F. Balatsky] (2006). Sumy: ITD "Universitetskaia kniga" [in Russian].

35. Noriganova, O. A. (2003). Metodologia otsenki turisticheskoy uslugi kak rynochnoy kategorii [Methodology for assessing tourism services as a market category]. Aktualni problemy ekonomiky, 2(13), 3742 [in Russian].

36. World Happiness Report 2016 (2016). [Electronic resource] / [edit. by J. Helliwell, R. Layard, J. Sachs]. New York : Sustainable Development Solutions Network, I. Retrieved from: http://worldhappiness.report/wp-content/uploads/sites/2/2016/03/HR-V1_web.pdf

37. Association Agreement between the European Union and its Member States, of the one part, and Ukraine, of the other part (2014). Official Journal of the European Union, OJ L 161, 29.5.2014, 3-2137. Retrieved from: https://eur-lex.europa.eu/legal-content/EN/ALL/?uri=CELEX\%3A22014A0529\%2801\%29

38. European integration portal (2017). Turyzm [Tourism], 27.09.2017. Retrieved from: http://euua.org/yevrointehratsiia/turyzm [in Ukrainian].

39. Strategy for the tourism and resorts development for the period up to 2026 (2017). Resolution of the Cabinet of Ministers of Ukraine №168-p, March 16, 2017. Retrieved from: https://zakon.rada.gov.ua/laws/show/168-2017-\%D1\%80\#Text

40. ISO (2020). COVID-19 response: freely available ISO standart. Retrieved from: https://www.iso.org/covid19

41. Crimea Development Program as a year-round national and international resort-recreational and tourist center (2003). Resolution of the Cabinet of Ministers of Ukraine №133, January 29, 2003. Retrieved from: https://zakon.rada.gov.ua/laws/show/133-2003-\%D0\%BF\#Text [in Ukrainian]. 